\title{
Succession of plant and soil microbial communities with restoration of abandoned land in the Loess Plateau, China
}

\author{
Jun-Jian Li • Yuan-Ming Zheng • Jun-Xia Yan • \\ Hong-Jian Li • Ji-Zheng He
}

Received: 3 August 2012 / Accepted: 10 January 2013 / Published online: 30 January 2013

(C) Springer-Verlag Berlin Heidelberg 2013

\begin{abstract}
Purpose There have been a number of studies on the succession of vegetation; however, the succession of soil microbes and the collaborative relationships between microbes and vegetation during land restoration remain poorly understood. The objectives of this study were to characterize soil microbial succession and to explore the collaborative mechanisms between microbes and vegetation during the restoration of abandoned land through quantitative ecology methods.

Materials and methods The present research was carried out in the succession of a 5-year abandoned land and its conversion to Hippophae rhamnoides shrubs, Larix principisrupprechtii plantation, and a naturally regenerated forest (mixed forest). Soil bacterial, archaeal and fungal characteristics were tested by real-time quantitative PCR assays and terminal restriction fragment length polymorphism. The richness, diversity, and evenness indices were employed to analyze plant and microbial communities' structure. The stability of plant and microbial communities was tested using Spearman's rank correlation. The relationships between the regeneration scenarios and environmental factors were determined through canonical correspondence analysis.

Results and discussion The aboveground biomass was significantly different among the sites. Soil bacterial, archaeal, and fungal rRNA gene abundances did not increase significantly
\end{abstract}

Responsible editor: Yanfen Wang

J.-J. Li · J.-X. Yan · H.-J. Li

Institute of Loess Plateau, Shanxi University, Taiyuan,

Shanxi 030006, People's Republic of China

J.-J. Li • Y.-M. Zheng $\cdot$ J.-Z. He ( $ه)$

State Key Laboratory of Urban and Regional Ecology,

Research Centre for Eco-environmental Sciences, Chinese Academy

of Sciences, Beijing 100085, People's Republic of China

e-mail: jzhe@rcees.ac.cn with increasing soil organic carbon content. There were higher correlation coefficients between plant and total microbial communities on the richness, diversity, and evenness indices and ratios of positive to negative association compared to ones between plant and individual bacteria, archaea, and fungi. Soil bulk density, clay, $\mathrm{pH}$, and litter were the primary significant environmental factors affecting the structure of plant and microbial communities. The positive relationships between plant and soil bacteria, fungi, and total microbe communities, as well as the negative relationships between plant and archaea, were demonstrated.

Conclusions The results suggested that plants promote the growth of soil bacteria and fungi during the process of community succession on a small scale; however, plants inhibit the growth of soil archaea.

Keywords Bacteria, archaea, and fungi · Community succession $\cdot$ Plant community $\cdot$ T-RFLP

\section{Introduction}

Soil microbes are known to play a key role in terrestrial ecosystem functions, such as carbon and nutrient cycling, plant growth stimulation, and degradation of organic matter. Understanding the spatial and temporal variability of microbial community structure and functions at a community level, e.g., in response to agricultural practices, to pollution, or to the climate (Smalla et al. 2007), is necessary. The cultivation of isolated microbes provides information that is useful for both the taxonomy and ecology of organisms. However, the obtained information was limited because an estimated $<1 \%$ of microorganisms can be cultured using traditional techniques (Nemergut et al. 2007). With the development of genetic profiling methods for soil microbial communities, such as denaturing or thermal gradient gel 
electrophoresis (Muyzer and Smalla 1998), single-strand conformation polymorphism (Schwieger and Tebbe 1998), ribosomal intergenic spacer analysis (Fisher and Triplett 1999), and terminal restriction fragment length polymorphism (T-RFLP) analyses (Liu et al. 1997), an increasing amount of important and detailed information on soil microbe ecology was provided. The genetic characteristics of the soil microbial community could be considered as an early indicator of assessing the status of the microbial ecosystem and, in the same vein, the quality of the soil and the progress of restoration after degradation (Harris 2003).

T-RFLP analysis is one of the most frequently used, highly reproducible genetic profiling methods (Osborn et al. 2000). The T-RFLP approach has been applied in the analysis of bacterial (McMahon et al. 2011; Tom-Petersen et al. 2003; Blackwood and Paul 2003; Hartmann et al. 2005), archaeal (Moeseneder et al. 2001; Leybo et al. 2006), and fungal (Bennett et al. 2008; Genney et al. 2006) rRNA genes, as well as functional genes such as ammoniaoxidizing (Fan et al. 2011), nitrogen-denitrifying (Wolsing and Priemé 2004), and dissimilatory (bi)sulfite reductase genes (Liu et al. 2009), among others. The profiles of TFRLP were analyzed using different methods, such as principal component analysis for the interpretation of the significance of the effects of complex T-RFLP patterns (Blackwood and Paul 2003; Wang et al. 2004; Park et al. 2006; Zhang et al. 2010), redundancy analysis for the analysis of T-RFLP data exhibiting a linear response to the environmental variables (Fan et al. 2011), canonical correspondence analysis (CCA) for the validation of the unimodal relationship between microbial communities and environmental factors (Chang et al. 2010), and multidimensional scaling (MDS) (Wolsing and Priemé 2004) and Nonmetric MDS (Bennett et al. 2008; Lee et al. 2010; McMahon et al. 2011) methods for estimating the similarities among samples. However, the interspecies (RFs) relationship within microbial communities cannot be described by these analysis methods. Spearman's rank correlation was used to assess the interspecific relationships within plant communities, and a higher species pair ratio of positive to negative association indicates a steadier structure of the plant community (Zhang et al. 2002).

A growing body of ecological research on plant-microbe interactions in soil during vegetation restoration has recently been conducted. This development suggests that afforestation alters the abundance of numerous microbial functional genes, thus correspondingly leading to changes in soil biogeochemistry, in part through the altered abundance of overall functional gene types rather than simply through changes in specific taxa (Berthrong et al. 2009). The target indigenous species of plants with a managed community of microbial symbionts were applied in the recovery of desertified ecosystems, which is a successful biotechnological tool (Requena et al. 2001). Positive and negative feedbacks between plants and soil microbes play central roles in early and later successional communities (Reynolds et al. 2003). Present conclusions were drawn from individual soil bacteria, archaea, and fungi, which were not treated as integral despite the fact that three kingdoms of microbes are known to interact with one another and jointly serve ecological functions.

Vegetation restoration is regarded as an effective strategy for controlling intensive soil erosion and its extensive effects (Oscar 2001; Cao et al. 2007). The farmland-toforest program was launched by the Chinese government to control serious soil erosion. Plant community characteristics during vegetation restoration in the Loess Plateau (Zhang et al. 2002; Hao et al. 2005; Xu et al. 2010) were reported in detail, and a number of reports on soil physicochemical properties were published (Hao et al. 2005; Li et al. 2011). In addition, soil microbial characteristics were studied using the culture method (Li et al. 2011). However, few reports exist on soil microbial characteristics determined using genetic profiling methods in the Loess Plateau.

To enhance the understanding on the effects of vegetation restoration on soil microbial ecological characteristics, soil bacterial, archaeal, and fungal rRNA genes were examined in the present study. Soil microbial rRNA gene abundance diversity indices were hypothesized to vary significantly with the soil organic carbon content, and highly similar community characteristics were demonstrated between plant and soil total microbes rather than the individual kingdom microbes (i.e., bacteria, archaea, and fungi, respectively).

\section{Materials and methods}

\subsection{Sampling and soil sample characteristics}

This research was conducted in the experimental region of Pangquangou Natural Reserve in the Lvliang Mountains $\left(111^{\circ} 21^{\prime}-111^{\circ} 37^{\prime}\right.$ E, $\left.37^{\circ} 45^{\prime}-37^{\circ} 59^{\prime} \mathrm{N}\right)$. There were a naturally regenerated forest (Mixed forest), Larix principisrupprechtii plantation (Plantation), and Hippophae rhamnoides shrubs (Shrub), which were established from an original field in 1973. The other study site was a large area of abandoned fields (Abandoned land) in 2003. The detailed study area, soil sampling, and analysis were described by Li et al. (2011).

To study the characteristics of the various plant communities under different restoration types, quadrats were set up in the study areas. Quadrats of $20 \times 20,4 \times 4$, and $1 \times 1 \mathrm{~m}$ were established in forest, scrubland, and grassland communities, respectively (Zhang 2005), and three samples were investigated. The cover, height, diameter at breast height (DBH), and the individual number for each tree species and the cover and height for shrubs and herbs were measured in each quadrat. 


\subsection{Aboveground biomass}

The herb in quadrats was respectively collected, dried, and weighted to assess the biomass.

The biomass of $H$. rhamnoides was calculated as

$W=-1.7866+0.5427 \mathrm{CH}$

The shrub biomass under tree was calculated as

$W=-97.6022+102.7280 \mathrm{CH}$

where $W$ and $\mathrm{CH}$ respectively represent the biomass (in grams per square meter) and crown width (in meters; Zhang et al. 1993).

The volume production of an individual tree could be obtained in the volume table (Science and Technology Department of Shanxi Forestry Bureau 1986) according to its DBH. The volume of a species $(V)$ was the sum of its individual tree's volume in a plot. The biomass of a species in a plot was calculated as

$W=V /(a+b V)$

where $V$ represents volume (in cubic meter per square, meter) of a species in a plot and $a$ and $b$ are constants (Zhou et al. 2002).

\subsection{DNA extraction}

DNA was extracted from $0.5 \mathrm{~g}$ fresh soil samples (sampled in August 2008) using Ultra-Clean ${ }^{\mathrm{TM}}$ soil DNA Isolation Kits (MoBio Laboratory, USA) according to the manufacturer's protocol. The extracted DNA was checked on a $1 \%$ agarose gel and the concentration and purity of the extracts were determined using a Nanodrops ND-1000 UV/Vis spectrophotometer (Nano-Drop Technologies, Wilmington, DE). The extracted DNA was used as a template to amplify soil bacterial, archaeal, and fungal rRNA genes.

\subsection{Quantification by real-time PCR assays}

The abundances of bacterial and archaeal $16 \mathrm{~S}$ and fungal $18 \mathrm{~S}$ rRNA genes were determined by quantitative real-time PCR method with the iCycler iQ5 thermocycler (Bio-Rad, USA; (He et al. 2007). Bacterial 16S rRNA gene was quantified by Taqman assays using the primers Bact1369FB and Prok1492R and the probe TM1389F (Suzuki et al. 2000). The 25- $\mu$ l reaction mixture included $12.5 \mu$ l of Premix Ex $\mathrm{Taq}^{\mathrm{TM}}$ (Takara Biotechnology, Japan), $1 \mu$ l of bovine serum albumin (BSA), $0.5 \mu \mathrm{l}$ of each primer $(10 \mu \mathrm{M})$, and $2 \mu \mathrm{l}$ of 100-fold diluted extracted RNA GENE as the template. Bacterial 16S rRNA gene was quantified as follows: $10 \mathrm{~s}$ at $95^{\circ} \mathrm{C}$ for the initial denaturation and 35 cycles of $15 \mathrm{~s}$ at $95{ }^{\circ} \mathrm{C}$, $1 \mathrm{~min}$ at $56^{\circ} \mathrm{C}$.
Ar364aF/Ar934b (Schellenberger et al. 2010) and NS1 /FUNG (May et al. 2001) were respectively used for determining the abundances of archaeal 16S rRNA and fungal 18S rRNA genes with the SYBR ${ }^{\circledR}$ Green I assays. The $25-\mu$ l reaction mixture consisted of $12.5 \mu \mathrm{l}$ of $\mathrm{SYBR}^{\circledR}$ Premix Ex $\mathrm{Taq}^{\mathrm{TM}}$ (Takara Biotechnology), $1 \mu \mathrm{l}$ of BSA, $0.5 \mu \mathrm{l}$ of each primer $(10 \mu \mathrm{M})$, and $2 \mu \mathrm{l}$ of 100 -fold diluted extracted DNA. Archaeal 16S rRNA gene was quantified as follows: $30 \mathrm{~s}$ at $94{ }^{\circ} \mathrm{C}$ for the initial denaturation and 40 cycles of $20 \mathrm{~s}$ at $94{ }^{\circ} \mathrm{C}$, $30 \mathrm{~s}$ at $59^{\circ} \mathrm{C}$, and $30 \mathrm{~s}$ at $72{ }^{\circ} \mathrm{C}$. Fungal $18 \mathrm{~S}$ rRNA gene was quantified as follows: $3 \mathrm{~min}$ at $95^{\circ} \mathrm{C}$ for the initial denaturation and 40 cycles of $10 \mathrm{~s}$ at $95^{\circ} \mathrm{C}, 30 \mathrm{~s}$ at $55^{\circ} \mathrm{C}$, and $1 \mathrm{~min}$ at $72^{\circ} \mathrm{C}$.

\subsection{T-RFLP analysis}

The 27F/1409R (Baker et al. 2003), Ar364aF/Ar934b, and NS1/FUNG primers were used to amplify fragments of the bacterial, archaeal, and fungal rRNA genes. In addition, the forward primers were labeled at the 5 '-end with 6carboxyfluorescein. To amplify the rRNA genes, $50 \mu$ of the PCR reactions was carried out according to the following reaction mixture: $5 \mu \mathrm{l} 10 \times$ PCR buffer $\left(\mathrm{MgCl}_{2}, 2 \mathrm{mM}\right), 4 \mu \mathrm{l}$ $2.5 \mathrm{mM}$ dNTPs, $0.5 \mu \mathrm{l}$ EX-Taq polymerase $\left(5 \mathrm{U}^{-1} \mathrm{l}^{-1}\right.$; Takara Biotechnology), $1 \mu \mathrm{l} \mathrm{BSA}$, and $4 \mu \mathrm{l}$ of 100 -fold diluted extracted DNA. Bacterial 16S rRNA gene PCR reactions were performed in the following program: 5 min at $94{ }^{\circ} \mathrm{C} ; 35$ cycles at $94{ }^{\circ} \mathrm{C}$ for $45 \mathrm{~s}, 54{ }^{\circ} \mathrm{C}$ for $45 \mathrm{~s}$, and $72{ }^{\circ} \mathrm{C}$ for $90 \mathrm{~s}$; followed by 10 -min extension at $72^{\circ} \mathrm{C}$. Archaea followed the following program: $94{ }^{\circ} \mathrm{C}$ for $5 \mathrm{~min} ; 35$ cycles of $45 \mathrm{~s}$ at $94{ }^{\circ} \mathrm{C}, 45 \mathrm{~s}$ at $58^{\circ} \mathrm{C}, 60 \mathrm{~s}$ at $72{ }^{\circ} \mathrm{C} ; 10 \mathrm{~min}$ at $72{ }^{\circ} \mathrm{C}$. Fungi $18 \mathrm{~S}$ rRNA gene PCR program was: $94^{\circ} \mathrm{C}$ for $5 \mathrm{~min} ; 35$ cycles of $30 \mathrm{~s}$ at $94^{\circ} \mathrm{C}$, $30 \mathrm{~s}$ at $56^{\circ} \mathrm{C}, 60 \mathrm{~s}$ at $72{ }^{\circ} \mathrm{C} ; 10 \mathrm{~min}$ at $72{ }^{\circ} \mathrm{C}$. After amplification, all PCR products were verified by $1 \%$ agarose gel electrophoresis and purified with Wizard ${ }^{\circledR}$ SV Gel and PCR Clean-Up System (Promega, USA).

The purified products were digested in separate reactions with restriction endonuclease HhaI and MspI (Takara Biotechnology) and incubated at $37^{\circ} \mathrm{C}$ for $3 \mathrm{~h}$ in the manufacturer's recommended reaction buffer. Digestions were in a total volume of $25 \mu$ l, including $4 \mathrm{U}$ of enzyme and about 500 ng DNA samples. The digestion products were further purified and a portion was mixed with deionized formamide and the internal standard GeneScan-ROX1000 (bacteria and archaea)/LIZ 500 (fungi) (Applied Biosystems). The mixtures were denatured for $3 \mathrm{~min}$ at $95{ }^{\circ} \mathrm{C}$ and the DNA fragments were size separated using a 3130xl Genetic Analyzer (Applied Biosystems).

\subsection{Statistical analysis}

A one-way analysis of variance (ANOVA) was used to examine the effects of vegetation types on the plant and soil microbe characteristics. Spearman's rank correlation was 
used to examine plant species pairs and microbial RF pairs association. These statistical analyses were performed using SPSS 13.0 for Windows.

Plant species importance values (IV) for each quadrat were calculated using the following formulas (Zhang and Dong 2010):

$\mathrm{IV}_{\text {tree }}=($ relative density + relative frequency + relative dominance $) / 3$

$\mathrm{IV}_{\text {shrub and herb }}$

$=($ relative coverage + relative height $) / 2$

IV plant community

$=\left(5 \times \mathrm{IV}_{\text {tree }}+2.5 \times \mathrm{IV}_{\text {shrub }}+2.5 \times \mathrm{IV}_{\text {grass }}\right) / 10$

We characterized plant species and RF richness, diversity, and evenness in each quadrat in order to reveal their variation among different restoration types. Four species diversity indices were employed.

(a) Species number as the richness index $(S)$

(b) Shannon-Wiener diversity index:

$$
H^{\prime}=-\sum P_{\mathrm{i}} \ln P_{i}
$$

(c) Simpson diversity index:

$$
D=1-\sum P_{i}^{2}
$$

(d) Pielou evenness index:

$$
E=H^{\prime} / \ln S
$$

For plant community, $S$ is the number of plant species, $P_{i}$ is the relative importance value of plant species $i, P_{i}=\mathrm{IV}_{i} / \mathrm{IV}$, $\mathrm{IV}_{i}$ is the importance value of species $i$, and IV is the sum of importance values for all species in a quadrate (Zhang and Dong 2010). For soil microbial community, $S$ is the number of RFs and $P_{i}$ is the relative ratio of RFs $i$ (Ge et al. 2008).

A matrix of IVs for plant and matrices of RF ratios for bacteria, archaea, fungi, and total microbe were used as the basis of the community analysis. According to quantification PCR, the ratios of logarithm of the bacterial, archaeal, and fungal rRNA gene copies approximate to 4:3:3. Matrix (- $^{-}$ total microbe $)=\left(4 \times\right.$ ratios $_{(\text {RFs-Bacteria })}+3 \times \operatorname{ratios}_{(\text {RFs-Archaea })}+3 \times$ $\left.\operatorname{ratios}_{(\mathrm{RFs}-\mathrm{Fungi})}\right) / 10$. A matrix of environmental values that were stated in $\mathrm{Li}$ et al. 2011 (environmental factors $\times$ quadrats) was also established, which were applied into analyzing the relationships between the regeneration scenarios and environmental factors using CCA. These calculations were carried out using the CANOCO4.5 (ter Braak and Šmilauer 2002), and the plant and microbial data were logarithmically transferred and applied in the analysis. The significance level $(P<0.05)$ between plant species (or microbial RFs) and environmental factors were analyzed by the Monte Carlo permutation test, and the tested significant environmental factors were applied into the final CCA.

\section{Results}

3.1 Aboveground biomass and soil bacterial, archaeal, and fungal abundance

The aboveground biomass under abandoned land and shrub were significantly lower than the two tree sites (Fig. 1). The aboveground biomass from mixed forest was significantly higher than the other sites.

No significant differences $(P>0.05)$ were detected in the soil bacterial and archaeal abundance, determined as $16 \mathrm{~S}$ rRNA gene copy numbers, among the different sites (Fig. 2a, b). Fungal 18S rRNA gene copy numbers in abandoned land and mixed forest were respectively the lowest and the highest, significantly different between them (see Fig. 2c). The ratios of the log number of soil bacteria, archaea, and fungi rRNA gene copies were approximately 4:3:3.

\subsection{Plant community composition and soil microbial} T-RFLP characteristics

Specific plant species were examined for each study site. The highest and lowest numbers of plant species respectively appeared in mixed forest and plantation. The highest important values from abandoned land, shrub, plantation, and mixed forest were 0.17 (Phragmites australis), 0.24 (Poa nemoralis), 0.22 (L. principis-rupprechtii), and 0.15 (Betula platyphylla), respectively.

The T-RFLP profiles of soil bacteria, archaea, and fungi rRNA genes from the sites were produced with $H h a \mathrm{I}$ and

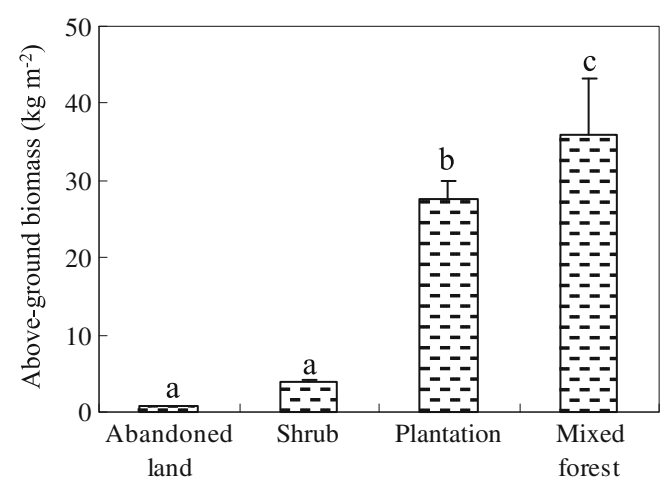

Fig. 1 Aboveground biomass from the sites in Loess Plateau. Columns are the means of three replicates; vertical bars are standard deviations. The same letter above the columns indicates that the means are not significantly different among the studied sites $(P<0.05)$ 

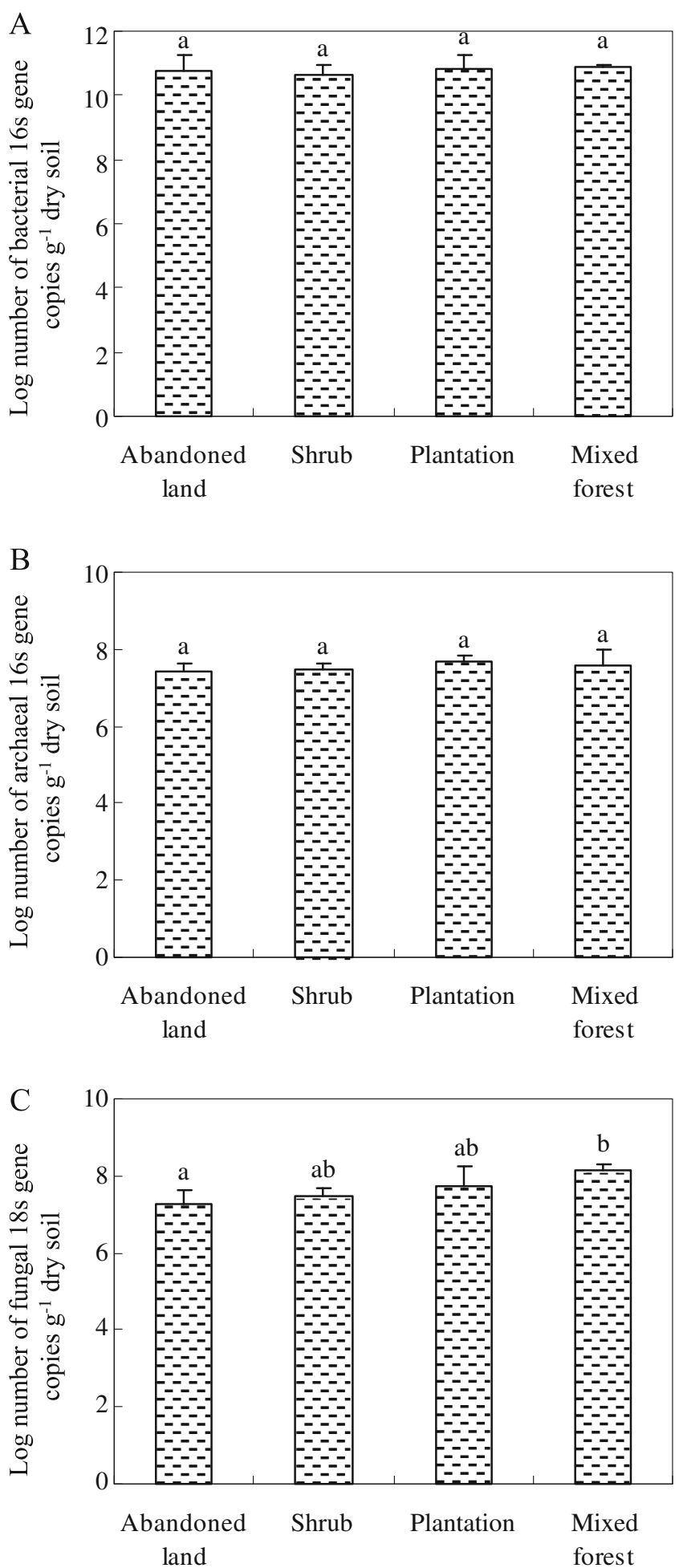

Fig. 2 Abundance of soil bacterial, archaeal, and fungal rRNA genes from the sites in Loess Plateau. Points are the means of three replicates; vertical bars are standard deviations. The same letter indicates that the means are not significantly different among the studied sites $(P<0.05)$

Ms $\mathrm{I}$ enzymes. Based on the relative fluorescence intensity of bacterial RFs restricted with $H h a \mathrm{I}$, we found that RFs with a size range from 50 to 100 bp occurred by nearly
$50 \%$, and a total of three, three, eight, and six specific RFs were found in abandoned land, shrub, plantation, and mixed forest, respectively. The relative fluorescence intensity of 98-bp archaeal RF was $43.80 \%$ and was highest in mixed forest; however, the highest relative intensity of RF was $320 \mathrm{bp}$ in the other sites. The T-RFLP profiles of soil fungi $18 \mathrm{~S}$ rRNA in shrub significantly differed from those of the three other sites. The relative abundance of RF restricted with $M s p I$ also demonstrated differences among sites.

\subsection{Plant and soil microbial diversity}

The plant species richness, diversity, and evenness indices are shown in Table 1. The species richness, Shannon-Wiener diversity, Pielou evenness, and Simpson diversity indices of the mixed forest were highest; however, the differences were insignificant, except for the richness index.

Table 2 shows the soil bacteria, archaea, fungi, and total microbe RF richness, diversity, and evenness indices according to RFs produced by HhaI. For soil bacterial RFs, the Shanon-Wiener and Simpson diversity and the Pielou evenness indices under abandoned land significantly differed from those of other sites, but no significant differences in terms of diversity indices were found among the sites. Soil archaeal RF richness and diversity indices did not display significant differences among the sites, and the Pielou evenness index of the mixed forest was significantly higher than those of abandoned land and plantation. Soil fungi RF diversity and evenness indices from shrub were significantly lower than those of the other sites where the differences were insignificant. When soil bacteria, archaea, and fungi were considered simultaneously, the richness, diversity, and evenness indices of soil total microbial RFs demonstrated no significant differences among the sites, which were very similar in terms of plant community. $T$ test showed that the effects of restriction endonuclease HhaI and $M s p I$ on soil microbial diversity indices varied among sites, microbial kingdoms, and indices.

\subsection{Effect of environmental factors on plant and soil microbial community composition and species distribution}

CCA revealed that the variation in plant and microbe communities can be attributed to environmental factors. The first two axes represented $37.9 \%$ of community variance, whereas $74.2 \%$ of the community indices were related to environmental variables. With vegetation evolution from grassland, scrubland, and woodland, the bulk density decreased and litter quantity and clay content increased (Fig. 3).

From Fig. 4, we found that the negative relationship between bulk density and litter, as well as clay, played noticeable roles in the soil bacteria community division. 
Table 1 Plant species richness index $(S)$, Shanon-Wiener diversity index $\left(H^{\prime}\right)$, Simpson diversity index $(D)$, and Pielou evenness index $(E)$

\begin{tabular}{lrlll}
\hline & \multicolumn{1}{c}{$S$} & $H^{\prime}$ & $D$ & $E$ \\
\hline Abandoned land & $10.67 \pm 2.08 \mathrm{a}$ & $2.44 \pm 0.47 \mathrm{a}$ & $0.74 \pm 0.11 \mathrm{a}$ & $1.03 \pm 0.11 \mathrm{a}$ \\
Shrub & $8.00 \pm 1.73 \mathrm{a}$ & $2.06 \pm 0.48 \mathrm{a}$ & $0.63 \pm 0.23 \mathrm{a}$ & $0.99 \pm 0.13 \mathrm{a}$ \\
Plantation & $9.67 \pm 1.53 \mathrm{a}$ & $2.34 \pm 0.44 \mathrm{a}$ & $0.66 \pm 0.02 \mathrm{a}$ & $1.03 \pm 0.13 \mathrm{a}$ \\
Mixed forest & $15.00 \pm 1.00 \mathrm{~b}$ & $3.05 \pm 0.23 \mathrm{a}$ & $0.63 \pm 0.03 \mathrm{a}$ & $1.13 \pm 0.08 \mathrm{a}$ \\
\hline
\end{tabular}

Data are the means \pm standard deviations. Values followed by the same letter do not differ $(P<0.05)$

Soil clay content was a significant environmental factor for the archaea community. Labile carbon, $\mathrm{pH}$, and bulk density were significant environmental factors for fungi, among which bulk density and $\mathrm{pH}$ were negatively correlated to the carbon content. The negative relationships also significantly affected the total microbe community. When we tested the relationship between soil microbial RFs produced by $M s p \mathrm{I}$ and environmental factors, $\mathrm{pH}$ and bulk density were significant factors for all microbial communities.

\subsection{Spearman's rank correlation test}

The results of Spearman's rank correlation test of the RF correlation of plants and soil microbes are listed in Tables 3 and 4, respectively. The higher plant species pair ratios of positive and negative associations appeared in shrub and mixed forest, and the lower ratios were observed in abandoned land and plantation (see Table 3). The higher RF pair ratios of positive and negative associations for soil bacteria, fungi, and total microbe were found in shrub and mixed forest; however, the higher ratios for soil archaea were found in abandoned land and plantation (see Table 4). In addition, the higher percentages of significant association
RF pair to all RF pair on soil bacteria, archaea, fungi, and total microbe were found in shrub and mixed forest.

\section{Discussion}

The aboveground biomass of the sites were undoubtedly significantly different because of the expansion in the vertical space from herb to shrub to tree (see Fig. 1), which partly contributed to the significant differences in litter and soil organic carbon ( $\mathrm{Li}$ et al. 2011). However, the differences were insignificant in terms of the abundance of soil bacteria, archaea, and fungi, except for the abundance of soil fungi embodied between abandoned land and mixed forest. This finding is contrary to the hypothesis that soil microbial abundance significantly develops with improving soil organic carbon ( $\mathrm{Li}$ et al. 2011). Two explanations can be interpreted for the stabilization phase of soil microbes: one is that the stabilization phase related with the maximum carrying capacity; the other is that the threshold values of important environmental properties have to be exceeded before key microbial groups can enter the ecosystem (van der Wal et al. 2006). The significant differences in fungi
Table 2 Soil bacteria, archaea, fungi, and total microbe RF richness index $(S)$, ShanonWiener diversity index $\left(H^{\prime}\right)$, Simpson diversity index $(D)$, and Pielou evenness index $(E)$

Data are the means \pm standard deviations. Values followed by the same letter do not differ $(P<0.05)$

\begin{tabular}{llllll}
\hline & & & & \\
& & & & \\
& & & \\
Bacteria & Abandoned land & $20.33 \pm 1.53 \mathrm{a}$ & $2.49 \pm 0.03 \mathrm{a}$ & $0.86 \pm 0.00 \mathrm{a}$ & $0.83 \pm 0.01 \mathrm{a}$ \\
& Shrub & $27.00 \pm 4.36 \mathrm{a}$ & $2.91 \pm 0.21 \mathrm{~b}$ & $0.92 \pm 0.02 \mathrm{~b}$ & $0.89 \pm 0.03 \mathrm{~b}$ \\
& Plantation & $28.33 \pm 5.51 \mathrm{a}$ & $2.88 \pm 0.26 \mathrm{~b}$ & $0.90 \pm 0.03 \mathrm{~b}$ & $0.86 \pm 0.02 \mathrm{ab}$ \\
& Mixed forest & $30.33 \pm 3.51 \mathrm{a}$ & $2.99 \pm 0.07 \mathrm{~b}$ & $0.92 \pm 0.00 \mathrm{~b}$ & $0.88 \pm 0.02 \mathrm{ab}$ \\
Archaea & Abandoned land & $4.67 \pm 0.58 \mathrm{a}$ & $0.87 \pm 0.06 \mathrm{a}$ & $0.48 \pm 0.07 \mathrm{a}$ & $0.57 \pm 0.04 \mathrm{a}$ \\
& Shrub & $3.33 \pm 0.58 \mathrm{a}$ & $0.89 \pm 0.04 \mathrm{a}$ & $0.50 \pm 0.04 \mathrm{a}$ & $0.76 \pm 0.13 \mathrm{ab}$ \\
& Plantation & $4.67 \pm 1.15 \mathrm{a}$ & $0.85 \pm 0.14 \mathrm{a}$ & $0.53 \pm 0.06 \mathrm{a}$ & $0.56 \pm 0.01 \mathrm{a}$ \\
& Mixed forest & $3.67 \pm 0.58 \mathrm{a}$ & $1.14 \pm 0.26 \mathrm{a}$ & $0.43 \pm 0.22 \mathrm{a}$ & $0.89 \pm 0.17 \mathrm{~b}$ \\
& Abandoned land & $9.67 \pm 1.53 \mathrm{~b}$ & $1.71 \pm 0.10 \mathrm{c}$ & $0.75 \pm 0.05 \mathrm{~b}$ & $0.76 \pm 0.05 \mathrm{~b}$ \\
& Shrub & $7.00 \pm 1.00 \mathrm{a}$ & $1.10 \pm 0.08 \mathrm{a}$ & $0.52 \pm 0.05 \mathrm{a}$ & $0.57 \pm 0.08 \mathrm{a}$ \\
& Plantation & $6.67 \pm 0.58 \mathrm{a}$ & $1.52 \pm 0.11 \mathrm{~b}$ & $0.75 \pm 0.04 \mathrm{~b}$ & $0.80 \pm 0.06 \mathrm{~b}$ \\
& Mixed forest & $8.67 \pm 1.15 \mathrm{ab}$ & $1.48 \pm 0.07 \mathrm{~b}$ & $0.70 \pm 0.01 \mathrm{~b}$ & $0.69 \pm 0.04 \mathrm{~b}$ \\
& Abandoned land & $34.67 \pm 2.52 \mathrm{a}$ & $2.86 \pm 0.06 \mathrm{a}$ & $0.91 \pm 0.01 \mathrm{a}$ & $0.81 \pm 0.01 \mathrm{a}$ \\
& Shrub & $37.33 \pm 4.51 \mathrm{a}$ & $2.99 \pm 0.21 \mathrm{a}$ & $0.85 \pm 0.09 \mathrm{a}$ & $0.83 \pm 0.08 \mathrm{a}$ \\
& Plantation & $39.67 \pm 6.11 \mathrm{a}$ & $2.98 \pm 0.11 \mathrm{a}$ & $0.92 \pm 0.01 \mathrm{a}$ & $0.81 \pm 0.00 \mathrm{a}$ \\
& Mixed forest & $42.67 \pm 3.21 \mathrm{a}$ & $3.05 \pm 0.04 \mathrm{a}$ & $0.93 \pm 0.01 \mathrm{a}$ & $0.81 \pm 0.03 \mathrm{a}$ \\
\hline
\end{tabular}




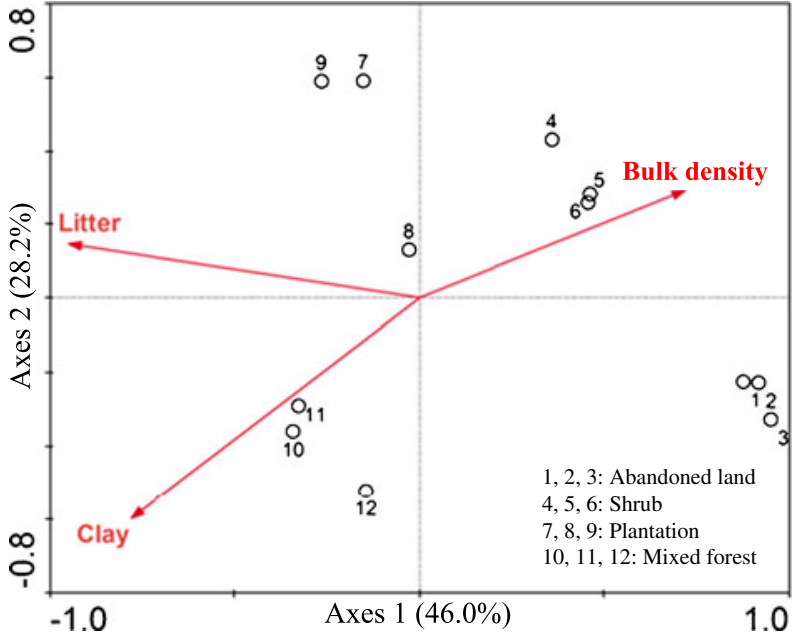

Fig. 3 CCA ordination biplot of 12 quadrats and environmental factors for plant community in Loess Plateau

abundance indicated that an increased amount of time is required to reach a constant level compared with bacteria and archaea. The increase in aboveground biomass and litter and the constant level of soil microbial respiration would allow the farmland-to-forest program to yield positive
Table 3 Results of Spearman's rank correlation test of the interspecies correlation of plant under different regeneration scenarios in Loess Plateau

\begin{tabular}{|c|c|c|c|c|c|c|}
\hline & \multicolumn{2}{|c|}{$\mathrm{SN}$} & \multicolumn{2}{|l|}{ IN } & \multirow[t]{2}{*}{ UN } & \multirow[t]{2}{*}{ Ratios } \\
\hline & + & - & + & - & & \\
\hline Abandoned land & 13 & 10 & 32 & 47 & 18 & 0.79 \\
\hline Shrub & 18 & 2 & 29 & 55 & 17 & 0.82 \\
\hline Plantation & 5 & 8 & 28 & 34 & 17 & 0.78 \\
\hline Mixed forest & 27 & 15 & 56 & 86 & 49 & 0.82 \\
\hline
\end{tabular}

$\mathrm{SN}$, IN, and UN are the species pair numbers of significant, insignificant, and uncorrelated association from Spearman rank correlation, respectively $(P<0.05)$

+ and - are respectively positive and negative associations

Ratios are plant species pair ratios of positive and negative associations

effects on the stock of soil carbon ( $\mathrm{Li}$ et al. 2011), thus confirming that soil is a carbon sink in the mid-latitude areas of the Northern Hemisphere (Tans et al. 1990).

Although less significant differences were found in terms of soil microbial abundance among the sites, specific RFs were found to be produced by either HhaI or MspI for each
Fig. 4 CCA ordination biplot of 12 quadrats and environmental factors for soil bacterial, archaeal, fungal, and total microbial communities in Loess Plateau
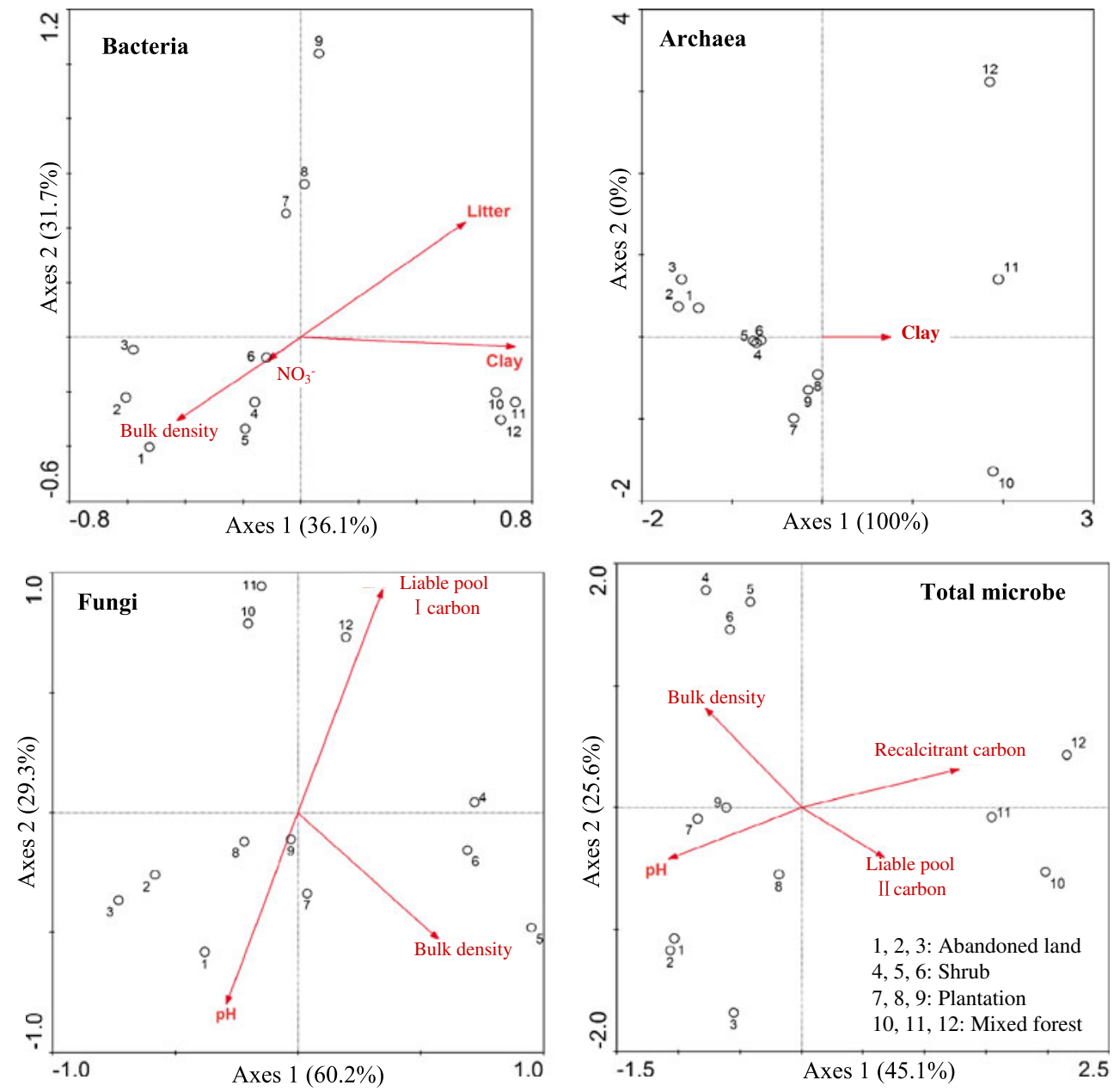
Table 4 Results of Spearman's rank correlation test of the interRF correlation of soil bacteria, archaea, fungi, and total microbe under different regeneration scenarios in Loess Plateau

\begin{tabular}{|c|c|c|c|c|c|c|c|}
\hline & & \multicolumn{2}{|l|}{ SN } & \multicolumn{2}{|l|}{ IN } & \multirow[t]{2}{*}{ UN } & \multirow[t]{2}{*}{ Ratios } \\
\hline & & + & - & + & - & & \\
\hline \multirow[t]{4}{*}{ Bacteria } & Abandoned land & 48 & 17 & 105 & 154 & 54 & 0.89 \\
\hline & Shrub & 109 & 51 & 133 & 152 & 116 & 1.19 \\
\hline & Plantation & 124 & 37 & 170 & 289 & 160 & 0.9 \\
\hline & Mixed forest & 118 & 78 & 159 & 224 & 69 & 0.92 \\
\hline \multirow[t]{4}{*}{ Archaea } & Abandoned land & 4 & 2 & 7 & 12 & 1 & 0.79 \\
\hline & Shrub & 0 & 2 & 2 & 2 & 0 & 0.5 \\
\hline & Plantation & 4 & 2 & 7 & 14 & 1 & 0.69 \\
\hline & Mixed forest & 1 & 2 & 3 & 4 & 0 & 0.67 \\
\hline \multirow[t]{4}{*}{ Fungi } & Abandoned land & 15 & 5 & 26 & 49 & 11 & 0.76 \\
\hline & Shrub & 3 & 5 & 13 & 11 & 4 & 1 \\
\hline & Plantation & 1 & 3 & 7 & 7 & 3 & 0.8 \\
\hline & Mixed forest & 5 & 8 & 11 & 12 & 11 & 0.8 \\
\hline \multirow[t]{4}{*}{ Total microbe } & Abandoned land & 144 & 62 & 354 & 506 & 210 & 0.88 \\
\hline & Shrub & 165 & 107 & 299 & 316 & 194 & 0.86 \\
\hline & Plantation & 202 & 127 & 398 & 566 & 248 & 0.87 \\
\hline & Mixed forest & 204 & 158 & 360 & 469 & 135 & 0.9 \\
\hline
\end{tabular}

$\mathrm{SN}, \mathrm{IN}$, and $\mathrm{UN}$ are the RF pair numbers of significant, insignificant, and uncorrelated association from Spearman's rank correlation, respectively $(P<0.05)$

+ and - are respectively positive and negative associations

Ratios are RF pair ratios of positive and negative associations and fungi. This finding was also supported by the quantity PCR results, wherein higher ratios of archaea to bacteria (and fungi) were found in abandoned land and plantations. This finding implies that soil archaea may play an important role during the primary rehabilitation stage after land abandonment, particularly in terms of poor soil fertility, which is attributable to archaea's high tolerance for environmental stress (Timonen and Bomberg 2009).

Indices of Shanon-Wiener diversity, Simpson diversity, and Pielou evenness for both plant and soil total microbes from the sites showed less significant differences, but an increasing level of significance was observed for soil bacteria, archaea, and fungi successively. This finding supports the hypothesis that higher similar community characteristics exist between plant and soil total microbes compared with bacteria, archaea, and fungi. This hypothesis is also supported by the results, indicating that significantly positive correlations on richness, Shanon-Wiener diversity, and Pielou evenness indices exist between plant and total microbes. However, four diversity indices of plants did not significantly correlate with soil bacteria, archaea, and fungi $(P<0.05$, not listed in the results). This phenomenon is attributable to the different ecological roles of soil bacteria, archaea, and fungi during the succession (Aller and Kemp 2008). In the present study, the different ecological roles of soil microbes were embodied in the slow succession of fungi as well as in the contrary succession trends between archaea and bacteria/fungi.

The restriction enzymes $H h a \mathrm{I}$ and MspI were widely applied in T-RFLP analysis (McMahon et al. 2011; Schütte et al. 2008). In the present work, very important information 
was provided by both $H h a \mathrm{I}$ and $M s p \mathrm{I}$, but the effect of the enzymes on soil microbial diversity indices differed because of the variance in soil microbial kingdoms and sites. The environmental factors most significantly correlated with specific individual kingdom microbes were similar for $H$ haI and $M s p \mathrm{I}$ in CCA, but the cumulative percentage variances of species-environment relations were different. Closer correlations in diversity indices often appeared between plant and microbial RFs restricted with MspI compared with those restricted with $H h a \mathrm{I}$, and similar trends are also demonstrated in the relationships in terms of the ratios of positive to negative associations between plants and microbes. MspI would be a more feasible restricted enzyme for the analysis of soil microbial community characteristics by T-RFLP.

\section{Conclusions}

Although significant differences on biomass were observed among sites, soil bacterial, archaeal, and fungal rRNA gene abundances did not differ significantly. Soil archaea may play a major role during the primary rehabilitation period. With the process of rehabilitation, soil physicochemical properties and organic matter improving, and soil bacteria and fungi take on more powerful growth advantages compared with archaea. Soil fungi will take longer to reach a constant level than bacteria and archaea. The combination of the T-RFLP method and quantitative ecological analyses provides a comprehensive way to analyze soil microbe ecological characteristics.

Acknowledgments This work was supported by the Natural Science Foundation of China (31070423, 41025004).

\section{References}

Aller JY, Kemp PF (2008) Are archaea inherently less diverse than bacteria in the same environments? FEMS Microbiol Ecol 65:74-87

Baker GC, Smith JJ, Cowan DA (2003) Review and re-analysis of domain-specific 16S primers. J Microbiol Meth 55:541-555

Bending GD, Turner MK, Jones JE (2002) Interactions between crop residue and soil organic matter quality and the functional diversity of soil microbial communities. Soil Biol Biochem 34:1073-1082

Bennett LT, Kasel S, Tibbits J (2008) Non-parametric multivariate comparisons of soil fungal composition: sensitivity to thresholds and indications of structural redundancy in T-RFLP data. Soil Biol Biochem 40:1601-1611

Berthrong ST, Schadt CW, Pinéiro G, Jackson RB (2009) Afforestation alters the composition of functional genes in soil and biogeochemical processes in South American grasslands. Appl Environ Microbiol 75:6240-6248

Blackwood CB, Paul EA (2003) Eubacterial community structure and population size within the soil light fraction, rhizosphere, and heavy fraction of several agricultural systems. Soil Biol Biochem $35: 1245-1255$
Cao S, Chen L, Xu C, Liu Z (2007) Impact of three soil types on afforestation in China's loess plateau: growth and survival of six tree species and their effects on soil properties. Landsc Urban Plan 83:208-217

Chang CY, Tung HH, Tseng IC, Wu JH, Liu YF, Lin HM (2010) Dynamics of methanotrophic communities in tropical alkaline landfill upland soil. Appl Soil Ecol 46:192-199

Fan F, Zhang F, Lu Y (2011) Linking plant identity and interspecific competition to soil nitrogen cycling through ammonia oxidizer communities. Soil Biol Biochem 43:46-54

Fang M, Motavalli PP, Kremer RJ, Nelson KA (2007) Assessing changes in soil microbial communities and carbon mineralization in $\mathrm{Bt}$ and non-Bt corn residue-amended soils. Appl Soil Ecol 37:150-160

Fisher MM, Triplett EW (1999) Automated approach for ribosomal intergenic spacer analysis of microbial diversity and ITS application to freshwater bacterial communities. Appl Environ Microbiol 65:4630-4636

Ge Y, He JZ, Zhu YG, Zhang J, Xu Z, Zhang LM, Zheng YM (2008) Differences in soil bacterial diversity: driven by contemporary disturbances or historical contingencies? ISME J 2:254-264

Genney DR, Anderson IC, Alexander IJ (2006) Fine-scale distribution of pine ectomycorrhizas and their extramatrical mycelium. New Phytol 170:381-390

Hao W, Liang Z, Chen C, Tang L (2005) Study of the different succession stage community dynamic and the evolution of soil characteristics of the old-field in Loess Hills Gully. Chin Agric Sci Bull 21:226-231

Harris JA (2003) Measurements of the soil microbial community for estimating the success of restoration. Eur J Soil Sci 54:801-808

Hartmann M, Frey B, Kflliker R, Widmer F (2005) Semi-automated genetic analyses of soil microbial communities: comparison of TRFLP and RISA based on descriptive and discriminative statistical approaches. J Microbiol Meth 61:349-360

He JZ, Shen JP, Zhang LM, Zhu YG, Zheng YM, Xu MG, Di HJ (2007) Quantification analysis of the abundance and composition of ammonia-oxidizing bacteria and ammonia-oxidizing archaea of a Chinese upland red soil under long-term fertilization practices. Environ Microbiol 9:2364-2374

Lee SH, Lee HJ, Kim SJ, Lee HM, Kang H, Kim YP (2010) Identification of airborne bacterial and fungal community structures in an urban area by T-RFLP analysis and quantitative real-time PCR. Sci Total Environ 408:1349-1357

Leybo AI, Netrusov A, Conrad R (2006) Effect of hydrogen concentration on the community structure of hydrogenotrophic methanogens studied by T-RFLP analysis of 16S rRNA gene amplicons. Microbiology 75:683-688

Li J, Li H, Zhou X, Zhao X, Yan J (2011) Labile and recalcitrant organic matter and microbial communities in soil after conversion of abandoned lands in the Loess Plateau, China. Soil Sci 176:313-325

Liu WT, Marsh TL, Cheng H, Forney LJ (1997) Characterization of microbial diversity by determining terminal restriction fragment length polymorphisms of genes encoding 16S rRNA. Appl Environ Microbiol 63:4516-4522

Liu XZ, Zhang LM, Prosser JI, He JZ (2009) Abundance and community structure of sulfate reducing prokaryotes in a paddy soil of southern China under different fertilization regimes. Soil Biol Biochem 41:687-694

May LA, Smiley B, Schmidt MG (2001) Comparative denaturing gradient gel electrophoresis analysis of fungal communities associated with whole plant corn silage. Can J Microbiol 47:829-841

McMahon SK, Wallenstein MD, Schimel JP (2011) A cross-seasonal comparison of active and total bacterial community composition in Arctic tundra soil using bromodeoxyuridine labeling. Soil Biol Biochem 43:287-295 
Moeseneder MM, Winter C, Arrieta JM, Herndl GJ (2001) Terminalrestriction fragment length polymorphism (T-RFLP) screening of a marine archaeal clone library to determine the different phylotypes. J Microbiol Meth 44:159-172

Muyzer G, Smalla K (1998) Application of denaturing gradient gel electrophoresis (DGGE) and temperature gradient gel electrophoresis (TGGE) in microbial ecology. Anton Leeuw 73:127-141

Nemergut DR, Anderson SP, Cleveland CC, Martin AP, Miller AE, Seimon A, Schmidt SK (2007) Microbial community succession in an unvegetated, recently deglaciated soil. Microb Ecol 53:110-122

Osborn AM, Moore ERB, Timmis KN (2000) An evaluation of terminal-restriction fragment length polymorphism (T-RFLP) analysis for the study of microbial community structure and dynamics. Environ Microbiol 2:39-50

Oscar C (2001) An analysis of externalities in agroforestry systems in the presence of land degradation. Ecol Econ 39:131-143

Park S, Ku YK, Seo MJ, Kim DY, Yeon JE, Lee KM, Jeong SC, Yoon WK, Harn CH, Kim HM (2006) Principal component analysis and discriminant analysis (PCA-DA) for discriminating profiles of terminal restriction fragment length polymorphism (T-RFLP) in soil bacterial communities. Soil Biol Biochem 38:2344-2349

Requena N, Perz-Solis E, Azcon-Aguilar C, Jeffries P, Barea J (2001) Management of indigenous plant-microbe symbioses aids restoration of desertified ecosystems. Appl Environ Microbiol 67:495-498

Reynolds HL, Packer A, Bever JD, Clay K (2003) Grassroots ecology: plant-microbe-soil interactions as drivers of plant community structure and dynamics. Ecology 84:2281-2291

Schellenberger S, Kolb S, Drake HL (2010) Metabolic responses of novel cellulolytic and saccharolytic agricultural soil bacteria to oxygen. Environ Microbiol 12:845-861

Schütte UME, Abdo Z, Bent SJ, Shyu C, Williams CJ, Pierson JD, Forney LJ (2008) Advances in the use of terminal restriction fragment length polymorphism (T-RFLP) analysis of 16S rRNA genes to characterize microbial communities. Appl Microbiol Biotechnol 80:365-380

Schwieger FS, Tebbe CC (1998) A new approach to utilize PCR single-strand-conformation polymorphism for 16S rRNA genebased microbial community analysis. Appl Environ Microbiol 64:4870-4876

Science and Technology Department of Shanxi Forestry Bureau (1986) The compilation of forestry standards in Shanxi Province Taiyuan, China

Shangguan T, Zhang F (1991) Investigation on vegetation and vertical distribution in the Yunding Mountain in Shanxi Province. J Mater Res 9:9-16

Smalla K, Oros-Sichler M, Milling A, Heuer H, Baumgarte S, Becker R, Neuber G, Kropf S, Ulrich A, Tebbe CC (2007) Bacterial diversity of soils assessed by DGGE, T-RFLP and SSCP fingerprints of PCRamplified 16S rRNA gene fragments: do the different methods provide similar results? J Microbiol Meth 69:470-479

Suzuki MT, Taylor LT, Delong EF (2000) Quantitative analysis of small-subunit rRNA genes in mixed microbial populations via 50-nuclease assays. Appl Environ Microbiol 66:4605-4614
Tans PP, Fung IY, Takahashi T (1990) Observational constraints on the global atmospheric carbon dioxide budget. Science 247:1431-1438

ter Braak CJF, Šmilauer P (2002) CANOCO reference manual and CanoDraw for Windows user's guide: software for canonical community ordination (version 4.5). Microcomputer Power, Ithaca, $500 \mathrm{pp}$

Timonen S, Bomberg M (2009) Archaea in dry soil environments. Phytochem Rev 8:505-518

Tom-Petersen A, Leser TD, Marsh TL, Nybroe O (2003) Effects of copper amendment on the bacterial community in agricultural soil analyzed by the T-RFLP technique. FEMS Microbiol Ecol 46:53-62

van der Wal A, van Veen JA, Smant W, Boschker HTS, Bloem J, Kardol P, van der Putten WH, de Boer W (2006) Fungal biomass development in a chronosequence of land abandonment. Soil Biol Biochem 38:51-60

Wang M, Ahrné S, Antonsson M, Molin G (2004) T-RFLP combined with principal component analysis and 16SrRNA gene sequencing: an effective strategy for comparison of fecal microbiota in infants of different ages. J Microbiol Meth 59:53-69

Wolsing M, Priemé A (2004) Observation of high seasonal variation in community structure of denitrifying bacteria in arable soil receiving artificial fertilizer and cattle manure by determining T-RFLP of nir gene fragments. FEMS Microbiol Ecol 48:261-271

Xu J, Li J, Bai Z, Yue J, Han J (2010) Effect of reclamation land soil to plant diversity in Antaibao Opencast Coal Mine Loess Zone: a case of discharged soil field in Antaibao Opencast Coal Mine. J Shanxi Agric Sci 38:48-51

Zak DR, Holmes WE, White DC, Peacock AD, Tilman D (2003) Plant diversity, soil microbial communities, and ecosystem function: are there any links? Ecology 84:2042-2050

Zhang J (2005) Succession analysis of plant communities in abandoned croplands in the Eastern Loess Plateau of China. J Arid Environ 63:458-474

Zhang J, Dong Y (2010) Factors affecting species diversity of plant communities and the restoration process in the loess area of China. Ecol Eng 36:345-350

Zhang F, Shangguan T, Li S (1993) Improvement on the modeling methods of biomass of brush. Chin J Ecol 12:67-69

Zhang F, Zhnag J, Han F (2002) Interspecific relationships and its environmental interpretation of the main tree species in the forest communities of Zhuweigou in Lishan Mountain Nature Reserve. Acta Phytoecol Sin 26:52-56

Zhang B, Deng H, Wang HL, Yin R, Hallett PD, Griffiths BS, Daniell TJ (2010) Does microbial habitat or community structure drive the functional stability of microbes to stresses following revegetation of a severely degraded soil? Soil Biol Biochem 42:850-859

Zhou GS, Wang YH, Jiang YL, Yang ZY (2002) Estimating biomass and net primary production from forest inventory data: a case study of China's Larix forest. For Ecol Manag 169:149-157 